\title{
Euplotes magnicirratus (Ciliophora, Hypotrichia) depends on its bacterial endosymbiont ' Candidatus Devosia euplotis' for food digestion
}

\author{
Claudia Vannini, Angela Schena, Franco Verni, Giovanna Rosati* \\ Dipartimento di Etologia, Ecologia ed Evoluzione, Università di Pisa, Italy
}

\begin{abstract}
A symbiotic relationship between the marine ciliate Euplotes magnicirratus and an alpha-proteobacterium has recently been described. The bacterial symbiont, identified by molecular analysis as a new species of the genus Devosia, is referred to with the provisional name 'Candidatus Devosia euplotis'. This association is constant (it was found in different ciliate strains sampled in different geographical regions), and durable (it persisted in laboratory conditions for years). The physiological significance of this association was investigated through antibiotically produced aposymbiotic E. magnicirratus and attempts to grow the endosymbionts outside their host. Aposymbiotic protozoa completely lost the ability to digest the green alga Dunaliella tertiolecta, their usual food in laboratory conditions, and died. An investigation into the different steps of the digestive process showed that acidification of the digestive vacuoles occurred normally in both symbiotic and aposymbiotic ciliates, but that subsequent activation of acid phosphatase did not occur in aposymbiotic cells. Therefore, the ciliate depends on the symbiont for digestion of its green algal food and, as a consequence, for its survival. Attempts to grow bacterial endosymbionts on diluted culture media and on ciliate homogenate were unsuccessful. The results indicate that this represents a new type of symbiosis between prokaryotes and ciliates, which is mutualistic, and most likely obligatory for both partners.
\end{abstract}

KEY WORDS: Alpha-proteobacteria - Ciliates - Devosia - Digestive process - Euplotes - Lysis · Symbiosis

\section{INTRODUCTION}

Prokaryotes living in ciliates were first reported over a century ago (Müller 1856). Since that time a series of well-established symbiotic relationships between ciliates and bacteria have been more or less thoroughly investigated. Studies are now mainly proceeding in 2 directions. First, molecular approaches have been used to identify and name some symbionts (Gromov \& Ossipov 1981, Preer \& Preer 1982, Quackenbush 1982, Heckmann \& Schmidt 1987). The phylogenetic affiliation has been determined for only a few of these, i.e. Caedibacter caryophilus (Springer et al. 1993), C. teniospiralis (Beier et al. 2002), Holospora obtusa (Amann et al. 1991), Polynucleobacter necessarius (Springer et al. 1996), and 'Candidatus Devosia euplotis' (Vannini et al. in press). Second, the significance of the symbiotic relationships and the possibility that the symbionts provide their host with selective advantages have been investigated. The association with prokaryotic organisms often appears to be important for ciliates in challenging environments. For example, most ciliates living in an anaerobic habitat host bacteria that can consume hydrogen as a substrate (Fenchel et al. 1977, Vogels et al. 1980, Fenchel \& Finlay 1991, Fenchel \& Bernard 1993). These ciliates could very likely exist without symbionts, but the latter enhance the ciliates' growth rate and yield (Fenchel \& Finlay 1991). Some associations may be ecologically advantageous but not vital for the ciliate host, e.g. Caedibacterinfected paramecia out-compete uninfected strains (Kusch et al. 2002) by their killing ability (for review see Preer et al. 1974). Other examples are the species of Euplotidium, which are defended from predation by peculiar symbionts referred to as epixenosomes (Rosati 1999, Rosati et al. 1999). In other cases, neither the 
symbiont nor the host can live without the other. A group of species of Euplotes, phylogenetically correlated despite differences in morphological and ecological characteristics (Petroni et al. 2002), harbour similar bacteria. The best-known species is Polynucleobacter necessarius, formerly omikron (Heckmann 1975), an endosymbiont of E. aediculatus (Heckmann et al. 1983). These endosymbionts are neither infectious nor pathogenic: they function more like an organelle. They are supposed to compensate for some metabolic deficiency that arose, probably, in a common ancestor of the group (Heckmann et al. 1986), but the deficiency has not been identified.

The physiological basis of a recently discovered symbiotic relationship is investigated in the present paper. This association involves the marine species Euplotes magnicirratus and an alpha-proteobacterium. The latter has been identified by molecular analysis as a new species of the Devosia genus. Until we succeed in cultivation, or additional phenotypic data become available, the bacterial species has been given the provisional name 'Candidatus Devosia euplotis' (Vannini et al. in press). This association was found in 3 different ciliate strains sampled in geographically disparate regions, and continuously maintained in the laboratory for years. Symbiont-free E. magnicirratus have never been found in nature, and a spontaneous loss of bacteria has never occurred in the laboratory.

This study was carried out using in vivo experiments, light and electron microscopy, cytochemistry and FISH.

\section{MATERIALS AND METHODS}

Ciliate culture conditions. Three ciliate strains from different geographical regions were studied: LIV5 from the Ligurian Sea (Italy), CO from the Caribbean Sea (Colombia), and CAMP4.4 from the Sardinian Sea (Italy). Through morphological observations and characterization of their 18S rRNA gene, they were all identified as Euplotes magnicirratus. The strains were obtained from cells isolated from marine samples and cultivated in artificial seawater (salinity $33 \%$ ) at $19^{\circ} \mathrm{C}$. Ciliates were regularly fed with pure cultures of the nanoflagellate Dunaliella tertiolecta (for details see Dini \& Nyberg 1994). All these strains are well known to consistently harbor 'Candidatus Devosia euplotis' as cytoplasmic bacterial endosymbionts (Vannini et al. in press). Strain LIV31 of Euplotes charon was cultured in the same way.

Electron microscopy. For scanning electron microscopy, ciliates were fixed in $2 \% \mathrm{OsO}_{4}$ in artificial seawater. The specimens were then placed on poly- $L$ lysine-coated cover slips, dehydrated in ethanol, and, after critical point drying, coated with gold and examined with a JEOL/JSM-5410. For transmission electron microscopy, both cells and cysts were fixed in $2.5 \%$ glutaraldehyde and $1 \% \mathrm{OsO}_{4}$ in cacodylate buffer $0.1 \mathrm{M}, \mathrm{pH}$ 7.4. After fixation, ciliates were dehydrated in ethanol and embedded in Epon812 resin. Thin sections were stained with uranyl acetate and lead citrate, and observed with a JEOL 100S. An estimate of the average number of endosymbionts per section was performed through the observation of 20 sections randomly chosen from 5 different ciliate cells.

Acid phosphatase activity was revealed cytochemically by the formation of an electron-dense lead precipitate. Samples fixed with glutaraldehyde (2\%) were incubated for $30 \mathrm{~min}$ at room temperature in a medium containing $8 \mathrm{mM} \beta$-glycerophosphate as substrate and lead ions as the capturing agent (Lewis 1977). They were then washed, post-fixed in $1 \% \mathrm{OsO}_{4}$ and processed for routine electron microscopy. Control samples were handled in the same way, but incubated in the absence of the substrate.

Detection of endosymbionts by FISH. Starved cells of Euplotes magnicirratus and E. charon were fixed for 5 min on microscope slides with $4 \%$ formaldehyde in PBS, then dehydrated in ethanol. Bacterial cells from growth media were also fixed with formaldehyde at $4^{\circ} \mathrm{C}$ for half an hour, washed with PBS, then put on slides and dehydrated. In situ hybridization was performed according to Manz et al. (1992) without formamide in the hybridization buffer. An absolute negative control (i.e. cells of other Euplotes species without endosymbionts) and a specific negative control (i.e. cells of other Euplotes species with different endosymbionts) were always added. Slides were then observed with a Zeiss microscope fitted for epifluorescence. Presence of endosymbionts was cheked using the species-specific probe DevEup_993 designed for this purpose (Vannini et al. in press).

Antibiotic treatments. Preliminary tests were performed to determine the suitable antibiotic treatment for the loss of symbionts. TEM observations and in situ hybridization with species-specific probe DevEup_993 revealed that a treatment of $5 \mathrm{~d}$ in a penicillin-G solution of $1000 \mathrm{U} \mathrm{ml}^{-1}$ (1 $\mathrm{U}$ is equivalent to $0.6 \mu \mathrm{g}$ of penicillin-G) in artificial sea water (salinity $33 \%$ ) led to a complete loss of the bacterial symbionts, without any damage to the ciliate host cell perceptible at the ultrastructural level. Moreover, the treated Euplotes magnicirratus cells still showed perfectly normal capacity of dividing and moving after $5 \mathrm{~d}$. Therefore, this kind of antibiotic treatment was always used in order to obtain symbiont-free E. magnicirratus cells. A control for each test was conducted with E. magnicirratus cells not treated with penicillin-G. It was impossible to culture an aposymbiotic strain of E. magnicirratus: aposymbiotic cells could be generated, but they could not be grown into a persistent culture. For this reason a strain 
of a closely related species, E. charon, devoid of bacterial symbionts, was also treated with penicillin-G, and used as a second control for each in vivo experiment.

Growth rate and digestion capacity evaluation of aposymbiotic ciliates. A first set of experiments was carried out to estimate the growth rate of aposymbiotic Euplotes magnicirratus. Twenty-one ciliate cells were isolated singly in 3-depression slides from mass cultures, fed with Dunaliella tertiolecta, and treated with penicillin-G (1000 $\left.\mathrm{U} \mathrm{ml}^{-1}\right)$. After $5 \mathrm{~d}$, resulting clones were transferred to the normal antibiotic-free culture medium and again fed with $D$. tertiolecta. The same number of cells was taken as a control, fed in the same way, and maintained in a penicillin-G-free medium. The number of cells in each depression was counted every $24 \mathrm{~h}$ for $10 \mathrm{~d}$ from the beginning of the experiment. The Kruskal-Wallis non-parametric test was used to make inferences about possible differences occurring among the experimental populations. A second set of experiments was performed to verify whether aposymbiotic ciliates were still able to digest their algal food or not. Thirty non-fed E. magnicirratus cells were treated with antibiotic for $5 \mathrm{~d}$, then transferred to culture medium and fed with $D$. tertiolecta for $5 \mathrm{~min}$. After this time, ciliates were again transferred to a medium completely free of food. Control cells not treated with penicillin were processed in exactly the same way. In vivo observations were performed both on treated and control ciliates every $8 \mathrm{~h}$ for $24 \mathrm{~h}$ with a Leitz D.I.C. (Differential Interference Contrast) photomicroscope. In order to verify the capacity of digesting $D$. tertiolecta during longer periods of time, ciliates were fed, treated with antibiotic, and observed with transmission electron microscopy after $10 \mathrm{~d}$ of starvation.

Analysis of the digestive process. Acridine orange (AO) is a weak base readily soluble in water that has no toxic effect on cells. In aqueous solution, the dye is present in 2 main forms. The first form is present in highly dilute solutions $\left(10^{-8} \mathrm{M}\right)$, in which the molecules are monomers and it is characterized by a green fluorescence emission with a maximum at $530 \mathrm{~nm}$. The second form, characteristic of a concentrated solution $\left(10^{-2} \mathrm{M}\right)$ in which the dye molecules are dimers, shows an orange-red emission with a maximum at $640 \mathrm{~nm}$. AO solutions of intermediate molarity possess mixed spectral characteristics. AO, as a weak base, tends to accumulate in acid compartments of the cell (Verni \& Gualtieri 1997, Landers et al. 2001), which can be easily recognized by the orange-red emission. To test whether the acidification of the digestive vacuole occurred or not in aposymbiotic ciliates, Euplotes magnicirratus specimens were treated with penicillin (1000 $\mathrm{U} \mathrm{ml}^{-1}$ ) and starved for $5 \mathrm{~d}$. The control specimens were starved for the same time without penicillin treatment. Control and treated specimens were placed in 2 vessels containing Dunaliella tertiolecta for $15 \mathrm{~min}$ then, after washing in sterilized seawater, transferred to AO solution $\left(10^{-8} \mathrm{M}\right)$. The same was done for control and treated cells not fed, as a control for AO. The specimens were then observed in vivo with a Leica microscope fitted for epifluorescence. Control and treated ciliate cells were handled in the same way (i.e. treated, fed, and washed) before fixing for AcPase localization.

Culture attempts of endosymbionts. Starved Euplotes magnicirratus cells were filtered and concentrated, then washed and homogenized. The homogenate was added to the culture medium and incubated at 28 and $19^{\circ} \mathrm{C}$. Attempts to grow endosymbionts were performed on nutrient agar (DIFCO) and nutrient broth (DIFCO) with $\mathrm{KH}_{2} \mathrm{PO}_{4} 0.45 \mathrm{~g} \mathrm{l}^{-1}$ and $\mathrm{Na}_{2} \mathrm{HPO}_{4} \cdot 12 \mathrm{H}_{2} \mathrm{O}$ pH 6.8 diluted $1 / 100$ as recommended by Janssen et al. (2002) for hardly cultivable bacteria. Attempts were also performed using ciliate homogenate as culture media, both in liquid and, added with agar $15 \mathrm{~g} \mathrm{l}^{-1}$ solid state. The presence of $E$. magnicirratus symbionts was regularly checked by in situ hybridization with the species-specific Probe DevEup_993 (Vannini et al. in press) together with Probe EUB338 complementary to almost all bacterial 16rRNA gene (Amann et al. 1990). Observations were carried on for 10 wk to detect slow-growing bacteria.

\section{RESULTS}

\section{The ciliate host}

The 3 Euplotes strains used in this study have been assigned to Euplotes magnicirratus Carter, 1972 based on the analysis of the morphological characters generally used to distinguish Euplotes species. They are oval in shape, ca. $57 \mu \mathrm{m}$ long and $43 \mu \mathrm{m}$ wide. On the flattened ventral surface (Fig. 1), a huge peristomial cavity extends up to $3 / 4$ of the whole length. On its left side, the oral membranelles are inserted ( $2 \mu \mathrm{m}$ apart from each other). Ten frontoventral, 5 transverse and 4 caudal cirri are also present. The convex dorsal surface (Fig. 2) presents 8 prominent ribs. Ribs separate 8 kineties each consisting of 13 to 17 dorsal bristles. The assignment of the 3 strains to this same species was congruent with the results obtained by comparative analysis of the 18S rRNA gene sequences. The sequences of the 3 strains are indeed identical (Petroni et al. 2002, Vannini et al. in press).

Cysts were occasionally found in each Euplotes magnicirratus strain grown in our lab in standard conditions; the stimuli which induce cyst formation are so far unknown. Cyst formation includes the loss of ciliary structures, cytoplasmic reorganization along with a sharp decrease in cell volume, and the formation of a cyst wall. 

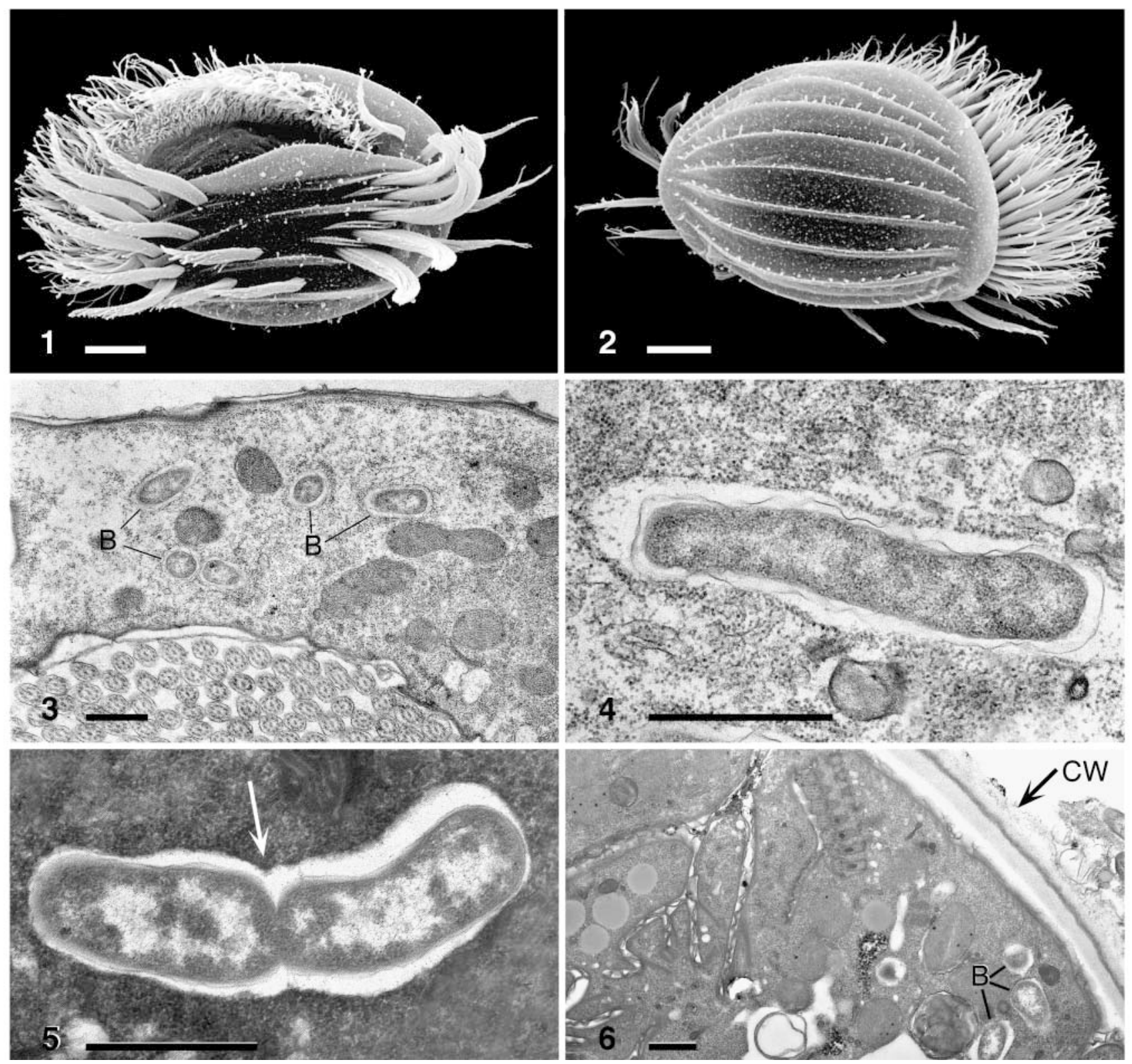

Figs. 1 \& 2. Euplotes magnicirratus under scanning electron microscope. Fig. 1. Ventral view. Fig. 2 . Dorsal view. Scale bars $=10 \mu \mathrm{m}$

Figs. 3 to 6. Euplotes magnicirratus, thin sections. Fig. 3. Cytoplasm portion, B: bacteria. Fig. 4. Symbiont at higher magnification. Fig. 5. Dividing symbiont. Arrow indicates the symbiosome invagination accompanying the bacterial division. Fig. 6 . Section of an encysted specimen. Bacteria (B) are still present. CW: cyst wall. Scale bars $=1 \mu \mathrm{m}$

\section{The symbiont}

Bacterial endosymbionts were found in all the specimens, independently of strain (CO, LIV5 or CAMP4.4). Their identity was demonstrated by in situ hybridization with species-specific probe DevEup993. Endosymbionts were never evidenced in the control, Euplotes charon. In all the 3 strains, the bacteria were morphologically identical at the ultrastructural level, equally distributed throughout the cytoplasm, and indi- vidually contained in vacuoles (symbiosomes) (Fig. 3). The presence of ribosomes along the external surface of the vacuoles indicates that the vacuole is provided by the host rough endoplasmic reticulum (Fig. 4). The symbionts are rod shaped, $0.5 \mu \mathrm{m}$ wide and up to $2.5 \mu \mathrm{m}$ long. They possess 2 membranes, the innermost of which is adherent to the protoplasm; the outermost is separated from the cell body by an irregular clear space (Fig. 4). The bacteria divide by transverse binary fission, accompanied by the division of the vacuole to the 
separate enclosure of each new bacterium (Fig. 5). The density of bacteria in the host cytoplasm was uniform. On the basis of 20 sections, randomly chosen from 5 different cells, the average number was 8.3 bacteria in a $100 \mu \mathrm{m}^{2}$ cytoplasmic area.

Bacteria were also always observed in well-formed cysts (Fig. 6), though they have never been seen in a dividing stage.

\section{Effects of symbiont deprivation}

Growth-rate evaluation

Once verified by in situ hybridization that bacteria actually disappeared from Euplotes magnicirratus cytoplasm after penicillin-G treatment, the growth rate and the general behavior of experimental and control specimens were compared. For this purpose, daily observations and counting of both samples were carried out during the $5 \mathrm{~d}$ of penicillin treatment, as well as over $5 \mathrm{~d}$ after the specimens were transferred to fresh sea water with food (a total observation period of $10 \mathrm{~d}$ ). The data thereafter reported (Figs. $7 \&$ 8) refer to Strain LIV5; corresponding results were obtained for CAMP4.4 and CO. The counting revealed statistically significant differences between the 2 series of specimens $\left(\mathrm{p}<10^{-5}\right)$ (Fig. 7). In the control specimens, a normal motile behavior was observed throughout the experiment, and the expected fission rate was maintained at least until the 8th day, when an increased mortality, presumably due to overcrowding, was recorded (Fig. 8). In the aposymbiotic specimens, although the cells were still able to divide, their abundance did not increase due to a progressive increase in mortality (Fig. 8). Moreover, direct observation showed that most surviving cells were swollen and motility had been altered.

No behavioral or reproductive differences were observed between treated and untreated Euplotes charon specimens.

At the end of the observation period, control and treated specimens were placed in appropriate vessels and handled as normal cultures. While controls revived completely, aposymbiotic cells never survived longer than a few weeks. Consequently, it was impossible to culture aposymbiotic strains of Euplotes magnicirratus.

\section{Digestion-capacity evaluation}

At the end of the above-described experiment, that is $5 \mathrm{~d}$ after the addition of new food organisms, cells collected from both experimental and control speci-

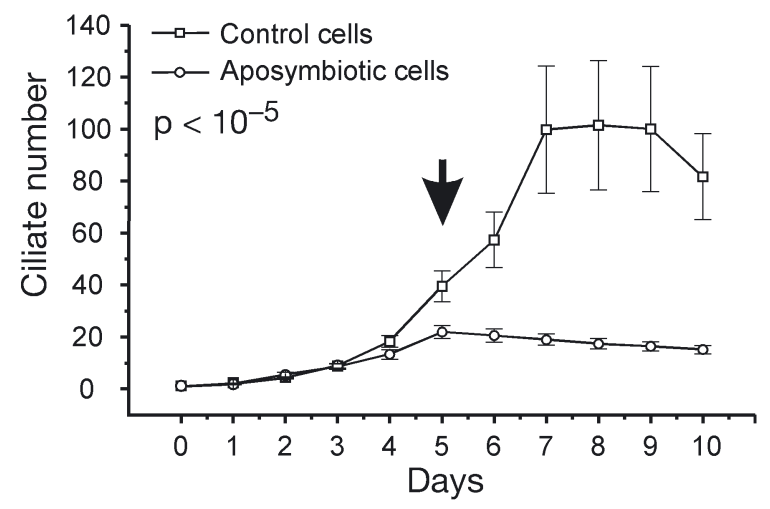

Fig. 7. Euplotes magnicirratus. Growth rate evaluation of control and aposymbiotic cells through ciliate abundance (means $\pm \mathrm{SE}, \mathrm{n}=21$ ). Arrow indicates the fifth day, i.e. the end of the penicillin-G treatment and the transfer of the cells to an antibiotic-free medium added with Dunaliella tertiolecta

mens were observed in vivo in the differential interference contrast microscope. Penicillin-treated Euplotes magnicirratus appeared full of the green microalgae they fed on, whilst food residues were not visible in the control cells, nor in treated or untreated E. charon.

Whether the loss of symbionts really influenced the digestive process in Euplotes magnicirratus was further determined by an ad hoc experiment, in which 30 treated and 30 control specimens were fed, washed and quickly transferred singly onto microscope slides (see 'Materials and methods'). They were then observed every $8 \mathrm{~h}$ to check the presence of algae contained in food vacuoles. Twenty-four hours later, the cytoplasm of the majority $(81.25 \%)$ of the control cells appeared completely transparent and devoid of visible digestive vacuoles (Fig. 9). In contrast, none $(0 \%)$ of

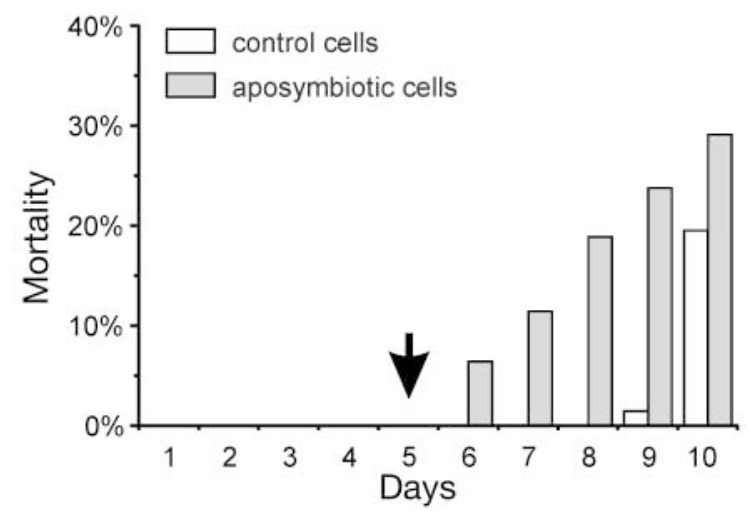

Fig. 8. Euplotes magnicirratus. Mortality percentage of control and aposymbiotic cells. Arrow indicates the fifth day, i.e. the end of the penicillin-G treatment and the transfer of the cells to an antibiotic-free medium added with Dunaliella tertiolecta. Observations and counting were carried out for $10 \mathrm{~d}$; after this period, all the aposymbiotic ciliates died within a few weeks 

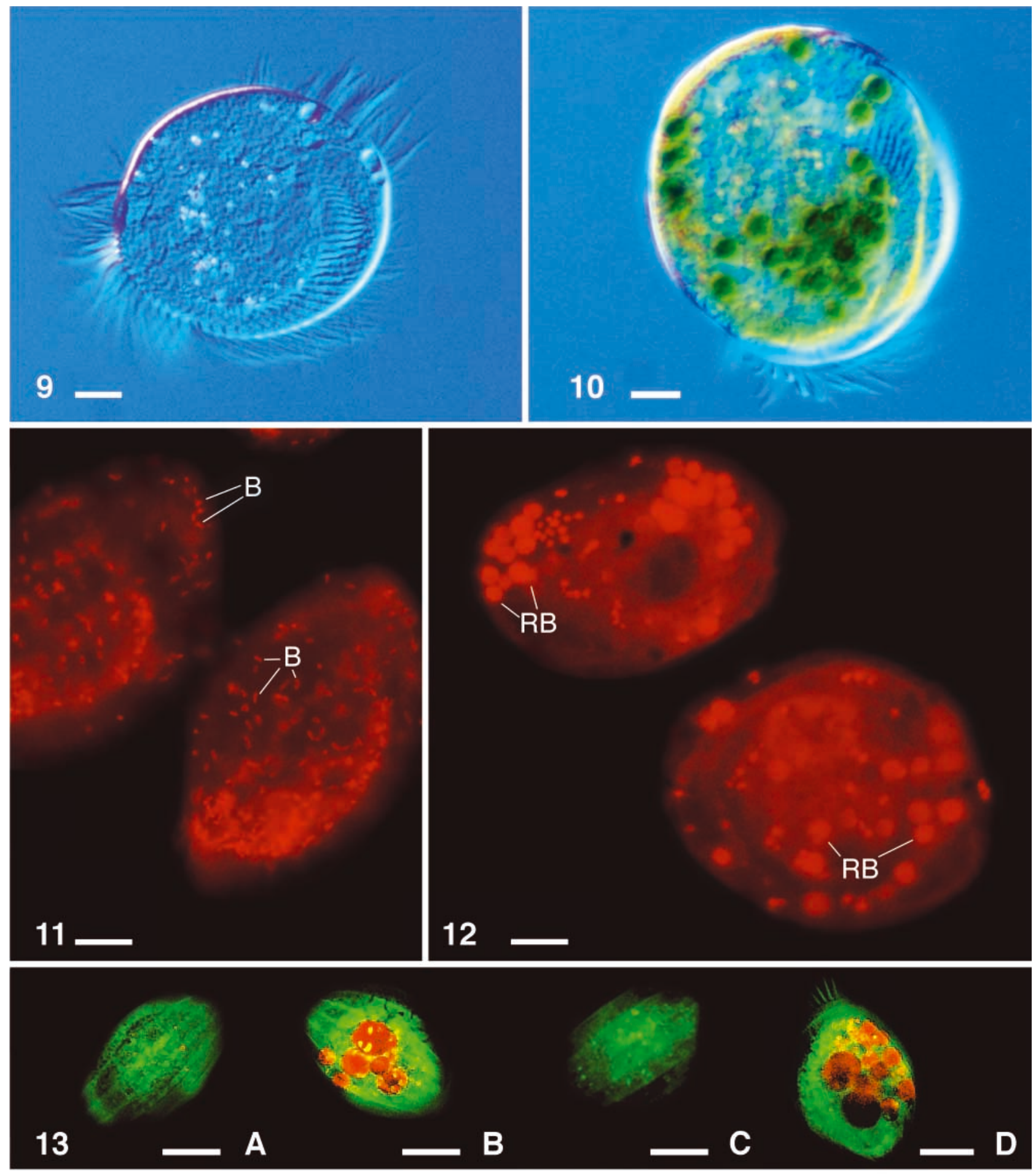

Figs. 9 \& 10. Euplotes magnicirratus digestion capacity evaluation in vivo. Fig. 9. Control cell: food algae not visible. Fig. 10. Penicillin-treated cell: green algae are clearly visible in the cytoplasm. Scale bars $=10 \mu \mathrm{m}$

Figs. 11 \& 12. Euplotes magnicirratus. In situ hybridization with DevEup_993 probe, specific for E. magnicirratus symbionts. Fig. 11. Control specimens. Bacteria (B) are clearly distinguishable in the cytoplasm. Fig. 12. Treated specimens. Bacteria are no longer recognizable. The fluorescent roundish bodies (RB) may be interpreted as undigested Dunaliella tertiolecta. Scale bars $=10 \mu \mathrm{m}$ Fig. 13. Euplotes magnicirratus. Acridine orange application. Starved control (A) and aposymbiotic (C) specimens. Fed control (B) and aposymbiotic (D) specimens. Acid compartments are visible by the orange-red emission. Scale bars $=20 \mu \mathrm{m}$ 
the aposymbiotic E. magnicirratus had completed its digestive process, and roundish green bodies, i.e. the food algae, could still be easily recognized inside the cells (Fig. 10).

TEM observations performed on aposymbiotic specimens after $10 \mathrm{~d}$ of starvation revealed the constant presence of morphologically intact algae (see Fig. 14), showing that digestion did not occur even over this longer period of time. These results agree with the observations performed by in situ hybridization with endosymbiont-specific Probe DevEup993. Indeed, the bacteria were clearly evidenced by this technique in untreated specimens (Fig. 11). However, in treated specimens, bacteria were no longer visible, but fluorescent roundish bodies were in the cytoplasm of treated and fed specimens. They can be interpreted as numerous undigested Dunaliella tertiolecta whose chloroplasts autofluorescenced (Fig. 12).

\section{Analysis of the digestive process}

Two different techniques, generally used to investigate the course of the digestive process in ciliates, were applied to both treated and untreated Euplotes magnicirratus. The first set of tests, performed with Acridine Orange, demonstrated that in both control and aposymbiotic specimens, acid food vacuoles are formed. The acid compartments are clearly visible by the high orange-red emission absent in the unfed ciliates (Fig. 13). This observation shows that the first step of the digestive process, that is the acidification of the digestive vacuole, occurs normally in aposymbiotic cells.

However, differences were evident in the next step of digestion, i.e. the activation of acid phosphatase. In digestive vacuoles of control specimens, algae were no longer recognisable and active acid phosphatase was revealed by a fine lead $(\mathrm{Pb})$ precipitate on the food remnants (Fig. 15). Interestingly, bacteria were often observed very close to, or even in contact with, the vacuolar membrane (Fig. 15). The vacuoles of treated, aposymbiotic specimens contained almost completely undigested algae. No sign of acid phosphatase activation was evidenced in them (Fig. 16).

\section{Culturing attempts of symbionts}

Euplotes magnicirratus symbionts were able to survive for no more than $3 \mathrm{wk}$ both in nutrient broth diluted 1/100 and in ciliate homogenate broth. During this period, the number of symbiont cells was never observed to increase significantly, and in ciliate homogenate symbionts were only present close to the remnants of destroyed ciliates. The absence of growth of endosymbionts outside their host was definitively confirmed by the results of culturing attempts on solid media. Growth of colonies of bacterial endosymbionts was never evidenced over the whole observation period (10 wk), either on diluted nutrient agar or on agarized ciliate homogenate.

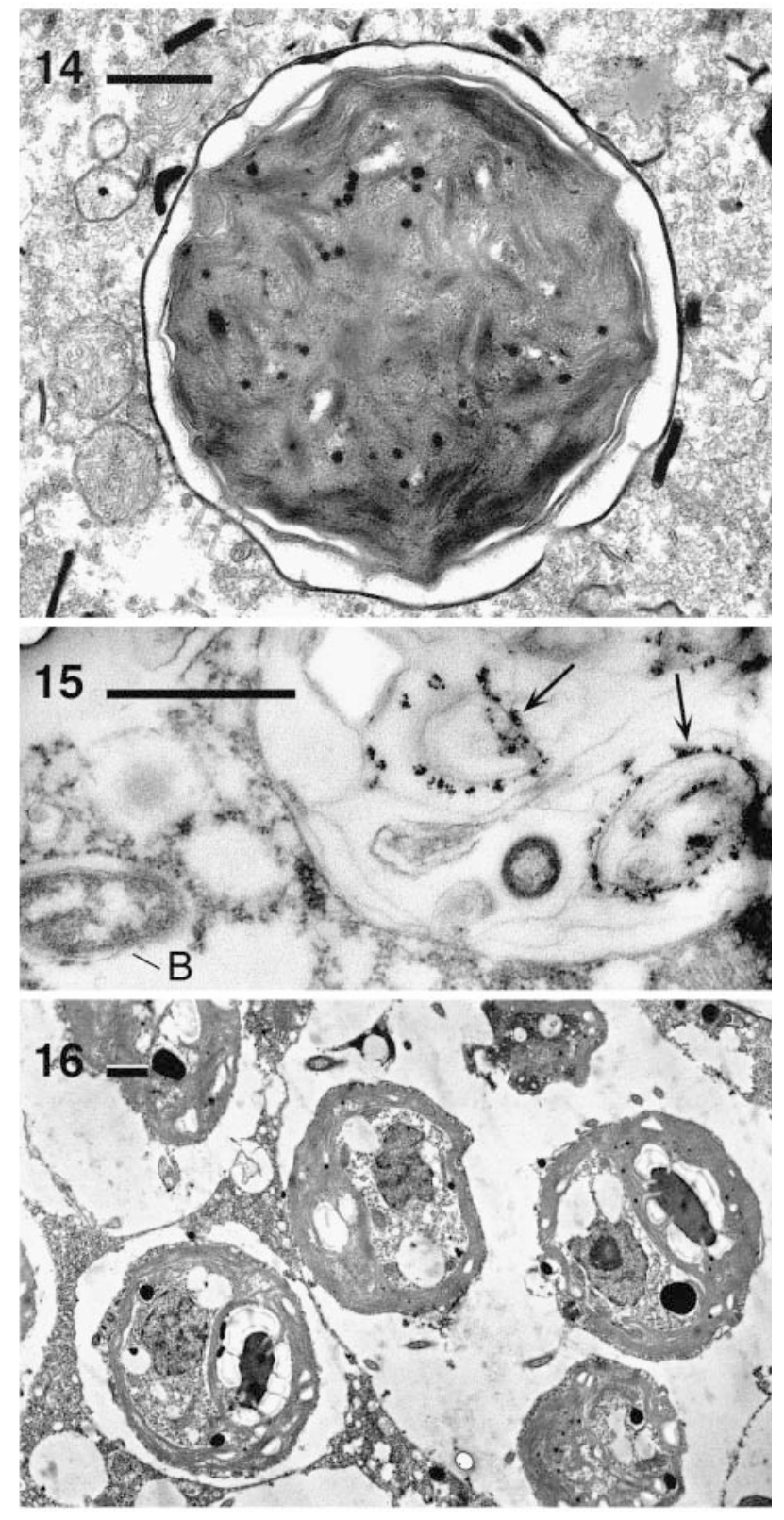

Fig. 14. An undigested alga Dunaliella tertiolecta still present in the cytoplasm of a penicillin treated Euplotes magnicirratus specimen after $10 \mathrm{~d}$ starvation. Scale bar $=1 \mu \mathrm{m}$

Figs. 15 \& 16. Active acid phosphatase detection. Fig. 15. In control Euplotes magnicirratus, the active enzyme is evidenced by lead precipitate on the remnant of food organisms inside digestive vacuoles. Arrows indicate the lead precipitate. B: bacterium. Fig. 16. In penicillin-treated aposymbiotic specimens, no active acid phosphatase is detected on vacuoles containing undigested algae. Scale bars $=1 \mu \mathrm{m}$ 


\section{DISCUSSION}

The results demonstrate that the symbiotic relationship between Euplotes magnicirratus and the alphaproteobacterium 'Candidatus Devosia euplotis' is well established and, most likely, obligatory for both partners. The symbiosis is constant in the natural environment and is always maintained in lab cultures, even when encystment occurs. The constancy in the symbiont density inside the host cytoplasm indicates a strict correlation between the reproductive cycles of the 2 partners. Furthermore, the average number of 8.3 bacteria in a $100 \mu^{2}$ cytoplasmic area is very high in comparison to values observed for other bacterial symbionts. In 2 strains of Euplotes crassus bearing endosymbionts, this number varied between 1.06 and 4 per $100 \mathrm{\mu m}^{2}$ in certain metabolic conditions (Rosati et al. 1981). Nobili et al. (1976) report a density value of 3.7 per $100 \mathrm{um}^{2}$ for the 'Eta killing particles' of Euplotes crassus, a symbiont facultative for the ciliate host. The high bacterial density found in the cytoplasm of E. magnicirratus is probably an expression of the close physiological relationship between the 2 partners. Indeed, once deprived of the bacteria the ciliates are no longer able to digest their usual food organism. On the other hand, negative results of the culturing attempts of 'Candidatus D. euplotis' outside the host indicate that these bacteria find in the ciliate cytoplasm a suitable, exclusive ecological niche.

Until now, only Polynucleobacter necessarius and the closely related omicron-like symbionts have been shown to be necessary for the survival of their ciliate hosts which, in their absence, are no longer able to divide (Heckmann 1975). The association described here represents a new finding of ciliates that die if deprived of the bacteria they harbour. This is clearly demonstrated by the results of the growth-rate tests. Despite the high variability, due to the different division rate of each isolate single cell, the differences between the control and the aposymbiotic ciliates are statistically significant.

All our observations indicate an association that involves mutual benefit. It is very likely that the host provides the bacteria with useful resources for their metabolism and, in return, the bacteria compensate metabolic deficiencies of the ciliate for a successful digestive process. The application of acridine orange demonstrated that newly formed phagosomes in aposymbiotic cells are acidified, as in control specimens. However, the successive steps of digestion do not take place in aposymbiotic ciliates, as evidenced by the lack of active acid phosphatase in undigestedalgae containing vacuoles. There are several examples, mainly among freshwater ciliates, of facultative associations with photosynthetic symbionts, particu- larly Chlorella; the ciliates appear to benefit from a reduced dependence from external food sources with a supplementary nutrition (Berninger et al. 1986, Landis 1988, Gu et al. 2002). In Euplotes, the presence of these kinds of symbionts has been reported only in E. daidaleos (Berninger et al. 1986). By far the most studied case is the frequently occurring symbiotic association between Paramecium bursaria and Chlorella (Bomford 1965). The algae are taken up in food vacuoles. Shortly after the acidification of the vacuoles, some algal cells are retained, apparently owing to special cell-wall surface components which trigger the formation of a special vacuolar membrane not recognized by lysosomes (Reisser et al. 1982, Meier \& Wiessner 1989). More recently, Takeda et al. (1998) proposed that the presence of glucosamine in the rigid wall of the algae is a prerequisite in determining the symbiotic association between Paramecium bursaria and Chlorella.

In symbiotized Euplotes magnicirratus, the digestive process was always found to proceed regularly. In our experimental conditions, most of the ingested algae disappeared from the cytoplasm within $24 \mathrm{~h}$. In contrast, ingested algae were always retained once the symbiotic bacteria had been eliminated. This phenomenon has been observed in many different experiments, carried out in different times and conditions in different penicillin-treated E. magnicirratus strains. Algal retention cannot be due to the treatment itself, as it was not observed either in E. charon, used in this study as a control, or in E. crassus treated with penicillin in previous studies (Nobili et al. 1976).

We have no indications whether undigested algae are modified in any way by acidification or if they still function inside the vacuoles of aposymbiotic Euplotes magnicirratus. Certainly, in contrast to the above-mentioned cases, they do not sustain its growth; instead, their accumulation in the cytoplasm renders the host swollen, slow in movement, and finally leads to its death. Therefore, the retention of algae in E. magnicirratus is not a physiological mechanism but a defective process.

The influence of symbiont deprivation on digestion of bacteria could not be tested. The experiments were performed in the lab, using a single algal species, namely Dunaliella tertiolecta, which does not possess a cell wall (Hoshaw \& Maluf 1981, Borowitzka \& Borowitzka 1988). E. magnicirratus is a filter-feeding ciliate, and very likely in the natural environment feeds on various organisms including bacteria. When only bacteria were provided to our cultures, the growth was slow and difficult. This difficulty indicates that bacteria are not the main component of this ciliate diet even in the natural environment. However, the lack of active acid phosphatase in aposymbiotic specimens indicates that the digestive process is interrupted independently 
of the food organism ingested. This could be due to the lack of metabolites provided by symbiotic bacteria needed for the activation of the lytic process.

Several mutualistic associations between bacteria and ciliates have been studied, but for only one of these was the precise metabolite supplied by the symbiont discovered. Lyticum flagellatum, a bacterial symbiont of Paramecium, is known to provide its host with folic acid (Soldo 1963, Soldo et al. 1982), although this association is facultative for both partners. Indeed, Lyticum flagellatum is lost when paramecia are cultured for some time, and, on the other hand, the bacteria can grow outside the host (Van Wagtendonk et al. 1963, Görtz 2002). The association between E. magnicirratus and its endosymbionts seems to be closer. The identity of the bacterial symbionts was unambiguously demonstrated in all the strains by 16S rDNA sequence analysis and species-specific in situ hybridization (Vannini et al. in press). The inability of 'Candidatus D. euplotis' to grow outside its host, on common media, on diluted media, or ciliate homogenate, strongly indicates that there is a deep adaptation to symbiotic life. Furthermore, the constant presence of endosymbionts inside the ciliate cysts, together with the absence of any observed dispersion of symbionts out of the hosts, points out the necessity of a vertical transmission of the bacteria. All these data support the hypothesis of an obligatory association between the 2 partners.

The association between Euplotes magnicirratus and 'Candidatus Devosia euplotis' seems to be speciesspecific. Indeed, in all E. magnicirratus strains examined here, regardless of the geographical region in which they were collected, the same bacterial species was unambiguously detected and, as far as we know, this ciliate species has never been described in association with other kinds of bacterial symbionts. Moreover, although E. magnicirratus and E. charon have the same size, habitat and presumably diet, in the latter neither bacterial symbionts nor retention of algae have ever been observed.

\section{LITERATURE CITED}

Amann RI, Krumholz L, Stahl DA (1990) Fluorescent oligonucleotide probing of whole cells for determinative, phylogenetic and environmental studies in microbiology. J Bacteriol 172:762-770

Amann RI, Springer N, Ludwig W, Görtz HD, Schleifer KH (1991) Identification in situ and phylogeny of uncultured bacterial endosymbionts. Nature 351:161-164

Beier CL, Horn M, Michel R, Schweikert M, Görtz HD, Wagner M (2002) The genus Caedibacter comprises endosymbionts of Paramecium spp. related to the Rickettsiales (alphaproteobacteria) and to Francisella tularensis (gammaproteobacteria). Appl Environ Microbol 68:6043-6050

Berninger UG, Finlay BJ, Canter HM (1986) The spatial distribution and ecology of zoochlorellaebearing ciliates in a productive pond. J Protozool 20:557-563

Bomford R (1965) Infection of algaefree Paramecium bursaria with strains of Chlorella, Scemedesnus and yeast. J Protozool 12:221-224

Borowitzka MA, Borowitzka LJ (1988) Dunaliella. In: Borowitzka MA, Borowitzka LJ (eds) Microalgal biotechnology. Cambridge University Press, Cambridge, p 27-58

Dini F, Nyberg D (1994) Adolescence and the reversibility of maturity in Euplotes crassus. J Eukaryot Microbiol 41: 361-368

Fenchel T, Bernard C (1993) Endosymbiotic purple non sulphur bacteria in an anaerobic ciliated protozoon. FEMS Microbiol Lett 110:21-25

Fenchel T, Finlay BJ (1991) The biology of freeliving anaerobic ciliates. Eur J Protistol 26:201-215

Fenchel T, Perry T, Thane A (1977) Anaerobiosis and symbiosis with bacteria in freeliving ciliates. J Protozool 24: $154-163$

Görtz HD (2002) Symbiotic associations between ciliates and prokaryotes. The prokaryotes. Electronic edition Release 3.11, Springer-Verlag, New York; available at: http:// link.springer-ny.com/link/service/books/10125/

Gromov BV, Ossipov DV (1981) Holospora (ex Hafkine 1890) nom. rev., a genus of bacteria inhabiting the nuclei of paramecia. Int J Syst Bacteriol 31:348-352

Gu F, Chen L, Ni B, Zhang X (2002) A comparative study on the electronic microscopic enzymocytochemistry of Paramecium bursaria from light and dark cultures. Eur J Protistol 38:267-278

Heckmann K (1975) Omikron, ein essentieller Endosymbiont von Euplotes aediculatus. J Protozool 22:97-104

Heckmann K, Schmidt HJ (1987) Polynucleobacter necessarius gen. nov., sp. nov. an obligate endosymbiotic bacterium living in the cytoplasm of Euplotes aediculatus. Int J Syst Bacteriol 37:456-457

Heckmann K, ten Hagen R, Görtz HD (1983) Freshwater Euplotes species with a 9-type cirrus pattern depend upon endosymbionts. J Protozool 30:284-289

Heckmann K, Schmidt HJ, Fujishima M (1986) Omikron and omikronlike endosymbionts of Euplotes. In: Wickner RB, Hinnebushch A, Lambowitz AM, Gunsalus IC, Hollaender A (eds) Extrachromosomal elements of lower eukaryotes. Plenum Press, New York, p 327-335

Hoshaw WH, Maluf LY (1981) Ultrastructure of the green flagellate Dunaliella tertiolecta (Chlorophyceae, Volvocales) with comparative notes on three other species. Phycologia 20:199-206

Janssen PH, Yates SP, Grinton BE, Taylor PM, Sait M (2002) Improved culturability of soil bacteria and isolation in pure culture of novel members of the divisions Acidobacteria, Actinobacteria, Proteobacteria and Verrucomicrobia. Appl Environ Microbiol 68:2391-2396

Kusch J, Czubatinski L, Wegmann S, Hübner M, Alter M, Albrecht P (2002) Competitive advantages of Caedibacterinfected Paramecia. Protist 153:47-58

Landers SC, Treadway RA, Johnson JW, Luckie RN (2001) Food plaquette digestion in the ciliated protozoan Hyalophysa chattoni. Invert Biol 120:97-103

Landis WG (1988) Ecology. In: Görtz HD (ed) Paramecium. Springer-Verlag, Berlin, p 419-436

Lewis PR (1977) Metal precipitation methods for hydrolitic enzymes. In: Glauert MA (ed) Staining methods for sectioned material. Staining methods for sectioned material. North Holland Publishing Company, Amsterdam, p 137-223

Manz W, Amann RI, Ludwig W, Wagner M, Schleifer KH (1992) Phylogenetic oligodeoxynucleotide probes for the 
major subclasses of proteobacteria: problems and solutions. Syst Appl Microbiol 15:593-600

Meier R, Wiessner W (1989) Infection of algae free Paramecium bursaria with aposymbiotic Chlorella sp. isolated from green paramecia. J Cell Sci 93:571-579

Müller M (1856) In Beobachtungen an Infusorien. Monatsberichte der Berliner Akademie, Berlin, p 389-393

Nobili R, Rosati G, Verni F (1976) The killer trait in Euplotes crassus (Ciliata, Hypotrichida). Bull Zool 43:251-258

Petroni G, Dini F, Verni F, Rosati G (2002) A molecular approach to the tangled intrageneric relationships underlying phylogeny in Euplotes (Ciliophora, Spirotrichea). Mol Phylogenet Evol 22:118-130

Preer JR Jr, Preer LB (1982) Revival of names of protozoan endosymbionts and proposal of Holospora caryophila nom. nov. Int J Syst Bacteriol 32:140-141

Preer JR Jr, Preer LB, Jurand A (1974) Kappa and other endosymbionts in Paramecium aurelia. Bacteriol Rev 38: 113-163

Quackenbush RL (1982) In validation of the publication of new names and new combinations previously published outside the IJSB. List no. 8. Int J Syst Bacteriol 32: 266-268

Reisser W, Radunz A, Wiessner W (1982) Participation of algal surface structures in cell recognition process during infection of aposymbiotic Paramecium bursaria with symbiotic chlorellae. Cytobios 33:39-50

Rosati G (1999) Epixenosomes: symbionts of the hypotrich ciliate Euplotidium itoi. Symbiosis 26:1-24

Rosati G, Verni F, Nobili R, Angeli M (1981) Starvation in Euplotes crassus (Ciliata, Hypotrichida): ultrastructure modifications and effects on reproduction. Acta Protozool 20:225-231

Rosati G, Petroni G, Quochi S, Modeo L, Verni F (1999) Epixenosomes: peculiar epibionts of the hypotrich ciliate Euplotidium itoi defend their host against predators. J Eukaryot Microbiol 46:278-282

Editorial responsibility: John Dolan, Villefranche-sur-Mer, France
Soldo AT (1963) Axenic culture of Paramecium: some observations on the growth behavior and nutritional requirements of a particlebearing strain of Paramecium aurelia 299 lambda. Ann NY Acad Sci 108:380-388

Soldo AT, Godoy GA, Brickson SA (1982) Growth requirements of symbiontfree and symbiont lambdabearing Paramecium octaurelia 299 for folic acid and biopterin. J Protozool 29:612-615

Springer N, Ludwig R, Amann R, Schmidt HJ, Görtz HD, Schleifer KH (1993) Occurrence of fragmented 16S rRNA in an obligate bacterial endosymbiont of Paramecium caudatum. Proc Natl Acad Sci USA 90:9892-9895

Springer N, Amann R, Ludwig W, Schleifer KH, Schmidt HJ (1996) Polynucleobacter necessarius, an obligate bacterial endosymbiont of the hypotrochous ciliate Euplotes aediculatus, is a member of the betasubclass of Proteobacteria. FEMS Microbiol Lett 135:333-336

Takeda H, Sekiguchi T, Nunokawa S, Usuki I (1998) Specificspecificity of Chlorella for establisment of symbiotic association with Paramecium bursaria-does infectivity depend upon sugar components of the cell wall? Eur J Protistol 34:133-137

Vannini C, Rosati G, Verni F, Petroni G (in press) Identification of the bacterial endosymbionts of the marine ciliate Euplotes magnicirratus (Ciliophora, Hypotrichia) and proposal of 'Candidatus Devosia euplotis' sp. nov. Int J Syst Evol Microbiol (in press) doi:10.1099/ijs.0.02759-0

Van Wagtendonk WJ, Clark JA, Godoy GA (1963) The biological status of lambda and related particles in Paramecium aurelia. Proc Natl Acad Sci USA 50:835-838

Verni F, Gualtieri P (1997) Digestive process of the raptorial feeder ciliate Litonotus lamella (Rabdophora, Litostomatea) visualized by fluorescence microscopy. Micron 28: $447-451$

Vogels GD, Hoppe WF, Stumm CK (1980) Association of methanogenic bacteria with rumen ciliates. Appl Environ Microbiol 40:4-11

Submitted: December 2, 2003; Accepted: February 27, 2004 Proofs received from author(s): June 4, 2004 